\title{
PENERAPAN PEMBELAJARAN PROBLEM BASED LEARNING UNTUK MENINGKATKAN KEMAMPUAN BERPIKIR KRITIS SISWA
}

\author{
NGATIYEM \\ MTs Darul A'Mal Metro Lampung \\ e-mail: ngatiyem1975@gmail.com
}

\begin{abstract}
ABSTRAK
Penelitian ini bertujuan untuk meningkatkan kemampuan siswa berpikir kritis melalui penerapan model pembelajaran Problem Based Learning pada siswa. Model ini jika diterapkan dengan baik dapat melatih siswa dalam memecahkan masalah kontekstual Tujuan penelitian ini adalah untuk meningkatkan kemampuan berpikir kritis siswa kelas IXH MTs Darul A'Mal Kota Metro melalui penerapan model Problem Based Learning pada materi kependudukan dan lingkungan Penelitian ini jenisnya adalah tindakan kelas (classroom action research) menggunakan model Kemmis dan Mc Taggart dimana setiap siklus terdiri dari perencanaan (planning), pelaksanaan (action) dan pengamatan (observe), serta refleksi (reflect). Peneliti bertindak sebagai perancang tindakan sekaligus sebagai pelaksana tindakan, sedangkan guru mitra bertindak sebagai observer. Penelitian dilaksanakan di MTs Darul A'Mal Metro pada bulan Agustus-September. Subjek penelitian yaitu siswa kelas IXH yang berjumlah 24 siswa laki-laki. Teknik pengumpulan data menggunakan lembar observasi kemampuan berpikir kritis , tes hasil belajar berpikir kritis, catatan lapangan, dan dokumentasi. Analisis data dilakukan dengan menganalisis data kualitatif yang terdiri dari reduksi data, penyajian data, verifikasi dan penarikan kesimpulan. Tindakan penelitian dikatakan berhasil apabila mencapai kriteria keberhasilan yang telah ditetapkan $\geq 75 \%$. Hasil penelitian berdasarkan observasi menunjukkan kemampuan berpikir kritis pada siklus I mencapai 57,80\%, sedangkan pada siklus II mencapai $79,38 \%$, yang berarti mengalami peningkatan sebesar 21,58\%. Berdasarkan hasil tes kemampuan berpikir kritis pada siklus I terdapat 54,17\% siswa yang mencapai kriteria ketuntasan, sedangkan pada siklus II menjadi 79,17\% tuntas KKM. Simpulan penelitian ini yaitu model pembelajaran Problem Based Learning dapat meningkatkan kemampuan berpikir kritis siswa pada materi kependudukan dan lingkungan pada siswa kelas IXH Tahun Pelajaran 2016/2017 MTs Darul A’Mal Kota Metro.
\end{abstract}

Kata Kunci: Problem Based Learning, Berpikir kritis

\section{ABSTRACT}

This study aims to improve students' critical thinking skills through the application of the Problem Based Learning model to students. This model, if applied properly, can train students in solving contextual problems. The purpose of this research is to improve the critical thinking skills of students in class IXH MTs Darul A'Mal Metro City through the application of the Problem Based Learning model on population and environmental materials. classroom action research) using the Kemmis and Mc Taggart model where each cycle consists of planning (planning), implementation (action) and observation (observe), and reflection (reflect). The researcher acts as the designer of the action as well as the executor of the action, while the partner teacher acts as an observer. The research was conducted at MTs Darul A'Mal Metro in August-September. The research subjects were students of class IXH, totaling 24 male students. Data collection techniques used critical thinking ability observation sheets, critical thinking learning outcomes tests, field notes, and documentation. Data analysis was carried out by analyzing qualitative data consisting of data reduction, data presentation, verification and drawing conclusions. The research action is said to be successful if it reaches the predetermined success criteria of $75 \%$. The results of the study based on observations showed critical thinking skills in the first cycle reached $57.80 \%$, while in the second cycle it reached $79.38 \%$, which means an increase of $21.58 \%$. Based on the results of the critical thinking ability test in the first cycle, there were $54.17 \%$ of students who achieved the criteria for completeness, while in the 
second cycle, $79.17 \%$ completed the KKM. The conclusion of this study is that the Problem Based Learning learning model can improve students' critical thinking skills on population and environmental material in class IXH students in the 2016/2017 academic year at MTs Darul A'Mal Metro City.

Keywords: Problem Based Learning, Critical Thinking

\section{PENDAHULUAN}

Kemampuan berpikir kritis merupakan kemampuan tingkat tinggi yang dapat ditumbuhkan dengan banyak berlatih untuk melihat suatu permasalahan yang terjadi dan mencarisolusi dalam menyelesaikan berbagai permasalahan kehidupan nyata yang dikaitkan dengan pengetahuan dari banyak sisi secara cermat, teliti, dan logis. Melalui kemampuannya berpikir kritis peserta didik dapat mempertimbangkan pendapat orang lain serta mampu menemukan ide dan gagasan serta mengungkapkan pendapatnya sendiri. Oleh karena itu pembelajaran di sekolah sebaiknya memberikan bentuk kegiatan yang mampu memotivasi siswa siswa untuk menggali kemampuan dan keterampilan dalam mencari, mengolah, dan menilai berbagai informasi secara kritis.

Kurikulum 2013 menghendaki perubahan pola pembelajaran yang sebelumnya berpusat pada guru (teacher Center) menjadi pembelajaran berpusat pada peserta didik (Student Center). Pembelajaran yang dilaksanakan harus dapat mengembangkan sikap, pengetahuan, dan keterampilan serta menerapkannya dalam berbagai situasi di sekolah dan masyarakat, salah satu kemampuan sikap adalah kemampuan berpikir kritis, terkait hal tersebut model pembelajaran Problem Based Learning erat kaitannya dengan karakteristik kemampuan berpikir kritis.

Model Problem Base Learning lebih menekankan pada usaha dalam menyelesaikan masalah melalui kegiatan penyelidikan. Kegiatan penyelidikan peserta didik ini tentunya membutuhkan informasi dari segala sumber, dan keterampilan mengolah informasi merupakan salah satu ciri dari kemampuan berpikir kritis. Menurut Asih dan Eka (2014) Hal yang paling mendasar dari Pembelajara Problem Base Learning adalah menghadirkan suatu bentuk permasalahan yang sesuai dengan fakta pada kesehariannya untuk diselidiki secara terbuka dan mencari solusi dari masalah tersebut. Oleh karena itu peran guru sangat penting, selain sebagai fasilitator, dan motivator guru juga harus kreatif memilih bentuk aktivitas kegiatan belajar yang mampu mendorong siswa untuk aktif secara fisik dan mentalnya sehingga pengalaman belajar yang diperoleh siswa benar-benar bermakna.

Hal ini di dukung oleh pernyataan Sani (2014) yang menjelaskan bahwa Pembelajaran Problem Base Learning menuntut siswa untuk aktif melakukan penyelidikan dalam menyelesaikan masalah dan guru berperan sebagai pembimbing. Pembelajaran ini akan membentuk kemampuan berpikir tingkat tinggi dan meningkatkan kemampuan siswa untuk berpikir kritis.

Selama ini berdasarkan pengalaman mengajar ini di MTs Daru A'Mal dalam kegiatan belajar masih cenderung menerapkan metode belajar yang sifatnya masih umum diterapkan seperti metode ceramah, guru memberikan tugas latihan soal-soal pada LKS atau buku paket yang biasa digunakan, selama kegiatan belajar jarang ada siswa yang mau mengajukan pertanyaan terkait materi yang dipelajari dan ketika guru bertanya hanya beberapa siswa saja yang mampu menjawab dengan baik, bahkan terkadang siswa memberi jawaban yang kurang logis. Dalam menyelesaikan tugas-tugas yang diberikan siswa malas membaca, tugas yang diberikan tidak dibaca secara cermat, malas mencari informasi sumber belajar yang tersedia, mereka hanya fokus pada buku LKS, sehingga kemampuannya dalam menggali informasi masih rendah, selain itu kemampuan menganalisis, persoalan tugas yang diberikan dan kemampuan menyusun kalimat jawaban tugas masih belum baik. Banyaknya gejala yang yang terjadi ini menunjukkan bahwa kemampuan berpikir kritisnya masih sangat rendah.

Munculnya berbagai permasalahan tersebut di duga karena guru belum melakukan perubahan pola mengajar, guru masih belum terampil dalam memilih metode mengajar yang sesuai dengan jenis materi yang akan diajarkan dan karakter siswa yang diajarnya, guru tidak 
menyajikan fakta yang terjadi dalam kehidupan sehari-hari, guru langsung memberikan konsep ilmu, padahal sesungguhnya IPA adalah ilmu sains dimana untuk mendapatkan suatu konsep harus melalui suatu proses dalam belajar dengan memaksimalkan semua aktivitas fisik dan mentalnya.

Solusi untuk mengatasi masalah pembelajaran yang dialami guru IPA di MTs Darul A;Mal adalah dengan merubah pola pembelajaran yang selama ini digunakan dengan menggantinya dengan pola baru, yaitu dengan mengganti metode mengajar salah satunya adalah dengan menerapkan model pembelajaran Problem Based Learrning yang dapat mengembangkan kemampuanya berpikir kritis siswa agar siswa terampil dalam menyelesaikan berbagai persoalan terkait materi pembelajaran maupun persoalan yang terjadi dalam kehidupan sehari-hari.

Model Pembelajaran Problem Based Learning dapat diterapkan untuk memecahkan masalah pembelajaran yang dialami guru dalam upaya meningkatkan kemampuan berpikir kritis siswa pada materi kependudukan dan lingkungan Kelas IXH MTs Darul A'Mal Kota Metro tahun pelajaran 2016/2017.

Merujuk pada hasil penelitian yang dilakukan oleh Asih dan Eka (2021) yang menunjukkan melalui penerapan model pembelajaran berbasis masalah mampu dan berhasil dalam meningkat kemampuan berpikir kritis dan belajar siswa. Di dukung oleh hasil penelitian yang dilakukan oleh Herzon dkk (2017) menunjukkan bahwa melalui pembelajaran Problem Based Learning proses kegiatan belajar dapat berlangsung lebih efektif dan efisien sehingga mampu meningkatkan keterampilan berpikir kritis peserta didik.

\section{METODE PENELITIAN}

Metode penelitian yang digunakan adalah penelitian tindakan kelas (PTK). Desain PTK dalam penelitian ini menggunakan model yang dikemukakan oleh Kemmis dan Mc Taggart (Sani dan Sudiran, 2016), yang terdiri dari 4 tahapan yaitu perencanaan, pelaksanaan, pengamatan dan refleksi. Model PTK berbentuk spiral berkelanjutan apabila target hasil tindakan yang dilakukan belum tercapai maka dilanjutkan dengan siklus berikutnya.

Subyek penelitian adalah siswa kelas IXH MTs Darul A'Mal Metro tahun pelajaran 2016 /2017 yang berjumlah 24 siswa semuanya laki-laki. Penelitian ini dilaksanakan secara kolaboratif dengan seorang guru IPA di Madrasah yang sama. Tindakan penelitian dilakukan dalam 2 siklus dengan masing-masing 2 kali dan 3 kali pertemuan, lama kegaiatan masingmasing pertemuan adalah 2 x 40 menit. Setiap berakhirnya siklus masing-masing diberikan tes hasil belajar kemampuan berpikir kritis.

Metode pengumpulan data penelitian ini meliputi : tes hasil belajar kemampuan berpikir kritis, dan observasi kemampuan berpikir kritis . Tes tulis diberikan pada awal siklus yang tujuannya adalah untuk mengetahui kemampuan awal dan tes hasil belajar kemampuan berpikir kritis dan dilaksanakan pada setiap akhir siklus. Tes berbentuk uraian dengan ketentuan keberhasilan penelitian adalah menghitung persentase jumlah siswa yang dapat mencapai KKM, jika ketuntasan $\geq 75$ dan sebanyak $75 \%$ siswa masuk kategori tuntas.

Sementara observasi kemampuan berpikir kritis dilakukan pada setiap kegiatan pembelajaran yang dilakukan bersama guru mitra dan dilaksanakan saat proses pembelajaran, langkahnya adalah dengan memberikan skor pada semua aspek berpikir kritis kepada semua siswa, kemudian menghitung persentase skor akhir dengan membagi skor yang diperoleh dengan skor maksimal. Aspek kemampuan berpikir kritis mengacu pada pendapat Ennis (komalasari, 2013) yang meliputi : kemampuan memberikan penjelasan sederhana, membangun keterampilan dasar, menyimpulkan, memberikan penjelasan lanjut dan mengatur strategi dan taktik. Selanjutnya hasil persentase kemampuan berpikir kritis yang diperoleh dikelompokkan dalam kualifikasi kemampuan berpikir kritis. data yang diperoleh dideskripsikan ke dalam lima kategori dengan mengacu pada kriteria yang ditetapkan yakni sangat tinggi, tinggi, sedang dan rendah. 
Data dalam penelitian ini berasal dari siswa kelas IXH MTs Darul A'Mal Kota Metro Tahun pelajaran 2016/2017, yang berjumlah 24 siswa. Sedangkan analisis data dilakukan dengan mendiskripsikan hasil pengamatan menggunakan lembar observasi menjadi data kuantitatif dan Tes Hasil Belajar siswa terkait matrei yang dipelajari. Data yang diperoleh berupa persentase hasil observasi tentang kemampuan berpikir kritis dalam aktivitas pembelajaran, dan Tes Hasil belajar terkait soal-soal berpikir kritis. Analisis data dilakukan secara simultan, sejak dilaksanakannya siklus I sampai terakhir.

\section{HASIL DAN PEMBAHASAN}

\section{Siklus I}

Pada pertemuan awal sebelum pelaksanaan tindakan guru mengadakan pretes untuk mengetahui kemampuan awal siswa dalam berpikir kritis, hasil tes rata-rata persentase kelas diperoleh 45,42 dari 24 siswa dengan nilai tertinggi 70 dan nilai terendah 20. Langkah selanjutnya adalah tindakan penerapan pembelajaran model Problem Base Learning. Penelitian ini dilaksanakan mulai tanggal 25 Agustus 2016 sampai dengan 15 September 2016 dilaksanakan sebanyak dua siklus, setiap siklus terdiri dari dua kali dan tiga kali pertemuan pada materi kependudukan dan lingkungan. Pembelajaran dengan Problem Base Learning dilaksanakan melalui 5 fase yang terdiri dari (1) Fase1: Memberikan orientasi tentang permasalahan kepada siswa; (2) Fase 2: Mengorganisasi siswa untuk meneliti; (3) Fase 3: Membantu investigasi mandiri dan berkelompok; (4) Fase 4: Mengembangkan dan menyajikan hasil karya; dan (5) Fase 5: Menganalisis dan mengevaluasi proses pemecahan masalah.

Pada pelaksanaan tindakan siklus I pertemuan kesatu dilaksanakan pada tanggal 25 agustus 2016 dengan menerapkan model pembelajaran Problem Base Learning dengan materi Dinamika penduduk. Langkah pertama yang dilakukan guru adalah membagi siswa dalam kelompok secara heterogen. Selanjutnya guru memberikan tugas tentang kepadatan penduduk yang selalu meningkat pertama siswa melakukan pendataan jumlah keluarga masing-masing siswa kemudian dan menjumlah anggota keluarga dalam satu kelompok yang berarti dalam skala kecil selanjutnya melakukan analisis sebab-sebab perubahan jumlah penduduk, selanjutnya setiap kelompok menjelaskan didepan kelas. Pada kelaksanaan pertama belum sepenuhnya berjalan dengan baik, karena masih tahap awal penerapan guru belum begitu terampil dalam menerapkan model Problem Base Learning.

Pada pertemuan kedua siklus I dilaksanakan tanggal 27 Agustus 2016 guru menyajikan grafik dinamika penduduk siswa diminta menganalisis data yang disajikan guru, dan memprediksi angka kelahiran dan kematian untk beberapa waktu kedepan. Setelah itu beberapa kelompok maju presentasi tetapi tidak semua mendapat kesempatan maju, karena pada pelaksanaan diskusi memakan waktu yang agak lama, guru kurang memperhatikan pembagian waktu untuk diskusi sehingga hanya satu kelompok saja yang presentasi. Pada kegiatan penutup guru mereviu beberapa hasil kerja diskusi masing-masing kelompok, dan memberikan penghargaan terhadap kelompok yang mampu bekerja dengan baik dalam menyelesaikan tugas.

Pelaksanaan pembelajaran pada siklus I secara umum sudah berjalan dengan baik meskipun masih ada beberapa temuan yang perlu diperbaiki. Pada setiap pertemuan dilakukan observasi kemampuan berpikir kritis yang dibantu oleh guru mitra serta dilaksanakan tes hasil belajar siklus I. Hasil observasi kemampuan berpikir kritis siklus I dapat dilihat pada Tabel 1.

Tabel 1. Hasil Observasi Pembelajaran Kemampuan Berpikir Kritis

\begin{tabular}{|l|c|c|}
\hline \multicolumn{1}{|c|}{ Aspek berpikir kritis } & Pertemuan I & Pertemuan II \\
\hline Memberikan Penjelasan sederhana & 63,54 & 57,12 \\
\hline Membangun keterampilan dasar & 52 & 59,64 \\
\hline Menyimpulkan & 55 & 61,81 \\
\hline Memberikan penjelasan lanjut & 57 & 60 \\
\hline Mengatur strategi dan taktik & 54 & 56,3 \\
\hline Total per pertemuan & 281,54 & 294,87 \\
\hline
\end{tabular}




\begin{tabular}{|c|c|c|}
\hline Rerata per pertemuan & 56,308 & 58,974 \\
\hline Total siklus I & \multicolumn{2}{|c|}{115,28} \\
\hline Persentase berpikir kritis siklus I & \multicolumn{2}{|c|}{57,80} \\
\hline Kategori & \multicolumn{2}{|c|}{ Rendah } \\
\hline
\end{tabular}

Setelah berakhirnya pelaksanaan tindakan siklus I dilaksanakan tes hasil belajar yang diikuti oleh 24 siswa pada materi kpendudukan, hasilnya diperoleh nilai tertinggi 85 dan nilai terendah 35. Siswa yang yang mampu memenuhi standar ketuntasan sebanyak 13 atau 54,17\% dan sisanya 11 siswa atau 45,83\% belum tuntas KKM. Hasil tes belajar siklus I dapat dilihat pada Tabel 2.

Tabel 2. Hasil Tes Belajar kemampuan berpikir kritis

\begin{tabular}{|l|c|c|}
\hline Jenis Tes & Pre tes & Tes siklus I \\
\hline Nilai Tertinggi & 70 & 85 \\
\hline Nilai Terendah & 20 & 35 \\
\hline Rerata & 45,42 & 61,80 \\
\hline Jumlah siswa yang tuntas & - & 13 \\
\hline
\end{tabular}

Berdasarkan Tabel 1. Hasil observasi kemampuan berpikir kritis siswa selama pembelajaran siklus I terjadi peningkatan dibeberapa aspek kemampuan berpikir kritis siswa, pada aspek kemapuan siswa dalam memberikan penjelasan sederhana justru menurun pada pertemuan ke-2 hal ini dikarenakan sebagian mengalami kesulitan membaca data bentuk tabel atau grafik, sehingga mengalami banyak kendala ketika menganalisis maksud dari permasalahan yang disajikan guru. Guru berupaya membantu menjelaskan cara memahami sajian data kependudukan dalam bentuk grafik ataupun tabel pada tiap kelompok sampai akhirnya setiap kelompok paham tetapi pada aspek yang lain mengalami peningkatan, kegiatan diskusi dalam berjalan dengan baik dalam kelompok terjalin komunikasi bekerja sama dalam menyelesaikan tugas yang diberikan.

Hasil kegiatan belajar siswa berdasarkan Tabel 2 juga mengalami perubahan dari hasil pretes, jika pada pretes siswa tidak ada yang tuntas KKM, tetapi pada siklus I terjadi peningkatan yaitu 13 siswa tuntas KKM. Hasil belajar ini dinyatakan masih belum berhasil, dikarenakan ketuntasan klasikal belajar kelas baru mencapai 54,17\%.

Berdasarkan Tabel 1 hasil observasi yang masih masuk kategori rendah dan Tabel 2, hasil belajar yang belum memenuhi standar ketuntasan yang ditetapkan dalam penelitian ini yakni 75\%, maka penelitian tindakan dilanjutkan pada siklus II dengan terlebih dahulu dievalusi kekurangan ataupun kelemahan yang ditemukan pada siklus I. Beberapa kekurangan yang ditemukan pada siklus I adalah Guru tidak memperhatikan manajemen waktu, pada kegiatan diskusi siswa menyita waktu yang lama, berpikir bersama menyelesaikan tugas guru dalam diskusi. Beberapa kelompok yang lambat menyelesaikan tugas dan ada kelompok yang tepat waktu, hal ini menunjukkan bahwa guru dalam membagi kelompok kurang heterogen, seharusnya dalam satu kelompok kemampuan anak beragam, yakni ada yang tinggi, kemampuan rendah maupun sedang. Terdapat perubahan aktivitas belajar siswa, dari yang tadinya duduk ditempat dan hanya mendengarkan, pada kegiatan pembelajaran model Problem Base Learning siswa melakukan aktivitas berpikir, berkomunikasi duduk dalam kelompok sehingga menumbuhkan jalinan komunikasi untuk mengungkapkan ide atau gagasan, siswa dalam kelompok berupaya menyelesaikan tugas. Dalam kegiatan belajar guru belum disiplin waktu, hal ini terlihat guru memberikan toleransi pada kelompok yang lambat dalam menyelesaikan tugas sehingga hanya beberapa kelompok saja yang mendapat kesempatan presentasi. Secara umum siswa tampak semangat dan antusias, dalam kelompok bekerja sama untuk menyelesaikan tugas. 


\section{Siklus II}

Siklus II berlangsung dalam tiga kali pertemuan kesatu dilaksanakan 3 september 2016 dengan materi dampak peningkatan jumlah penduduk terhadap lingkungan. Kegiatan awal dimulai guru melakukan apersepsi dengan memberikan beberapa pertanyaan terkait materi, beberapa siswa menanggapai dan guru memberi respon dan menguatkan jawaban siswa. Selanjutnya guru membagi kelompok dan membagi tugas kelompok terkait dengan jumlah keluarga dan banyaknya sampah yang dihasilkan, kemudian memprediksi jumlah sampah rumah tangga dalam beberapa waktu mendatang serta mencari solusi terkait sampah yang dihasilkan. Secara berkelompok dalam diskusi bersama menyelesaikan tugas, kemudian guru meminta kelompok maju menjelaskan tugas yang diberikan. Kemudian setelah beberapa kelompok presentasi guru memberikan penilaian terhadap kelompok yang memiliki de dan gagasan yang baik.

Pertemuan kedua dilaksanakan 8 september 2016, dengan materi dampak peningkatan jumlah penduduk terkait ketersediaan air dan dampak terhadap limbah yang dihasilkan. Secara kooperatif siswa berpikir, berkomunikasi bersama menyelesaikan permasalah yang disajikan siswa diminta untuk mengungkapkan idenya dalam upaya mengatasi pencemaran maupun upaya dalam menjaga ketersediaan air bersih. Pada kegiatan penutup guru memberikan penghargaan terhadap kelompok yang mampu bekerjasama dengan baik dan siswa yang memiliki ide yang logis terkait permasalahan yang sedang dibahas.

Pertemuan ketiga dilaksanakan pada 10 september 2016, pada awal kegiatan guru memberikan apersepsi terkait ketersediaan pangan terhadap peningkatan jumlah penduduk, guru mengajukan sebagai stimulasi, siswa merespon pertanyaan guru dilanjutkan dengan penyampaian tujuan pembelajaran. Pada kegiatan inti siswa bekerja dalam kelompok diskusi, selanjutnya guru membagi tugas terkait permasalahan pencemaran lingkungan tanah dan udara dampak dari peningkatan jumlah penduduk dan kebutuhan primer manusia. Selesai diskusi beberapa perwakilan kelompok presentasi. Dan pada kegiatan penutup guru memberikan penilaian dan penghargaan pada kelompok yang presentasi baik, serta kelompok yang memunculkan gagasan serta ide-ide dalam upaya mengatasi pencemaran pencemaran tanah dan udara.pada kegiatan penutup guru dan siswa bersama menyimpulkan kegiatan pembelajaran.

Selama pembelajaran, selalu dilaksanakan observasi penilaian diskusi pada setiap siswa pada semua aspek berpikir kritis selanjutnya hasil observasi jumlah dan di rata-rata. Hasil observasi kemampuan berpikir kritis pada siklus II terlihat pada Tabel 3.

Tabel 3. Hasil Observasi Kemampuan berpikir Kritis pada siklus II

\begin{tabular}{|l|c|c|c|}
\hline \multicolumn{1}{|c|}{ Aspek berpikir kritis } & $\begin{array}{c}\text { Pertemuan 1 } \\
(\%)\end{array}$ & $\begin{array}{c}\text { Pertemuan 2 } \\
(\%)\end{array}$ & $\begin{array}{c}\text { Pertemuan } \\
3(\%)\end{array}$ \\
\hline Memberikan Penjelasan sederhana & 79,34 & 75,87 & 81,42 \\
\hline Membangun keterampilan dasar & 76,56 & 78,13 & 81,51 \\
\hline Menyimpulkan & 72,22 & 87,50 & 77,08 \\
\hline Memberikan penjelasan lanjut & 72,00 & 80,00 & 81,00 \\
\hline Mengatur strategi dan taktik & 85.00 & 88,00 & 75,00 \\
\hline Total per pertemuan & 385,12 & 409,5 & 396,01 \\
\hline Rerata per pertemuan & 77,02 & 81,90 & 79,20 \\
\hline Total siklus I & \multicolumn{3}{|c|}{238,13} \\
\hline Persentase berpikir kritis siklus II & T9,38 \\
\hline Kategori & Tinggi \\
\hline
\end{tabular}

Setelah berakhirnya materi pembelajaran pada siklus II dilaksanakan tes hasil belajar kemampuan berpikir kritis siswa. Data hasil Tes siklus II dapat dilihat pada siklus Tabel 4.

Tabel 4. Hasil Tes Belajar kemampuan berpikir kritis

\begin{tabular}{|c|c|}
\hline \multicolumn{1}{|c|}{ Jenis Tes } & Tes siklus II \\
\hline Nilai Tertinggi & 90 \\
\hline
\end{tabular}




\begin{tabular}{|l|c|}
\hline Nilai Terendah & 55 \\
\hline Rerata & 77,08 \\
\hline Jumlah siswa yang tuntas & 19 \\
\hline
\end{tabular}

\section{Pembahasan}

Secara umum berdasarkan Tabel 1 dan 3 rata-rata kemampuan berpikir kritis siklus I sebesar 57,80\% dengan kategori rendah, sedangkan pada siklus II mengalami peningkatan mencapai 79,38\% kategori tinggi . Semua indikator kemampuan berpikir kritis mengalami peningkatan yang cukup signifikan, seperti terlihat pada Gambar 1.

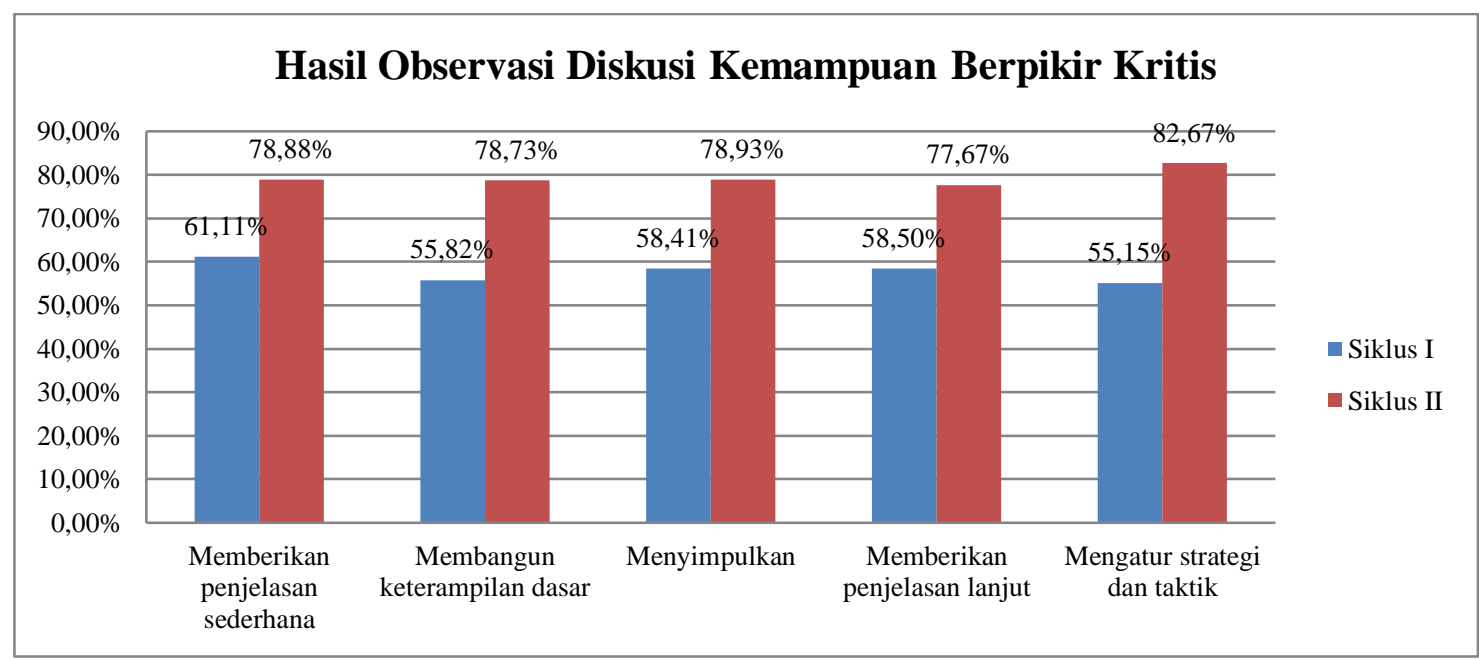

Gambar 1. Hasil Observasi Kemampuan berpikir Kritis

Peningkatan hasil observasi kemampuan berpikir pada kegiatan pembelajaran mengalami peningkatan, hal ini karena Guru secara umum sudah mulai terbiasa dalam melaksanakan langkah-langkah pembelajaran Problem Base Learning yang telah disusun dalam RPP dengan baik, dalam pelaksanaannya guru telah memberikan contoh permasalahan yang diambil dari masalah-masalah lingkungan. Dalam pembelajarannya guru mengakomodasi seluruh kelompok untuk aktif bersama dalam kelompok untuk mengenali masalah, berpikir bersama dan mencari refrensi penyelesaian tugas, sehingga siswa memaksimakan aktifitas fisik dan mentalnya bersama.

Pada siklus II, pada pembelajaran guru sudah membagi kelompok antara siswa dengan kemampuan tinggi, sedang dan rendah sudah mulai merata, sehingga semua kelompok bisa menyelesaikan tugas dengan baik. Pada kegiatan ini guru terus memotivasi agar siswa memperbanyak membaca dari banyak sumber, agar semakin memperkaya pengetahuan, karena model pembelajaran Problem Base Learning mendorong siswa untuk tidak hanya sekedar berpikir yang bersifat konkret, tetapi lebih dari itu mampu berpikir terhadap ide-ide yang abstrak dan kompleks, contoh yang disajikan sesuai dengan kehidupan nyata maka pembelajaran menjadi lebih bermakna dan menarik.

Keunggulan dalam pembelajaran berbasis masalah menurut Kemendikbud (2013b) adalah menjadikan pembelajaran yang bermakna, dimana siswa akan memecahkan masalah dengan menerapkan pengetahuan yang dimiliki atau berusaha mencari pengetahuan untuk yang diperlukan, belajar jadi lebih bermakna dan dapat diperluas ketika peserta didik berhadapan dengan situasi konsep diterapkan. Selain itu dengan pembelajaran berbasis masalah dapat meningkatkan kemampuan berpikir kritis siswa, dan dapat menumbuhkan inisiatif untuk bekerja, motivasi internal untuk belajar dan mengembangkan hubungan interpersonal dalam bekerja kelompok.

Lebih lanjut Trianto (2011) menjelaskan bahwa pada model pembelajaran berbasis masalah dalam kelompok kecil siswa bekerja bersama memecahkan suatu masalah yang telah 
disepakati oleh guru dan siswa, ketika guru sedang menerapkan model pembelajaran tersebut seringkali siswa menggunakan bermacam-macam keterampilan, proedur pemecahan masalah dan berpikir kritis. Dalam pembelajaran berdasarkan masalah dilandasi oleh teori belajar kontruktivis.

Secara umum tes hasil belajar kemampuan berpikir kritis mengalami peningkatan, sebelum siklus dilaksanakan pretes kemampuan berpikir kritis dengan rata-rata diperoleh 45,42 dan pada siklus I meningkat menjadi 61,80 sedangkan pada siklus II berhasil mengalami peningkatan mencapai 77,08. Tes hasil belajar dapat dilihat seperti pada Gambar 2.

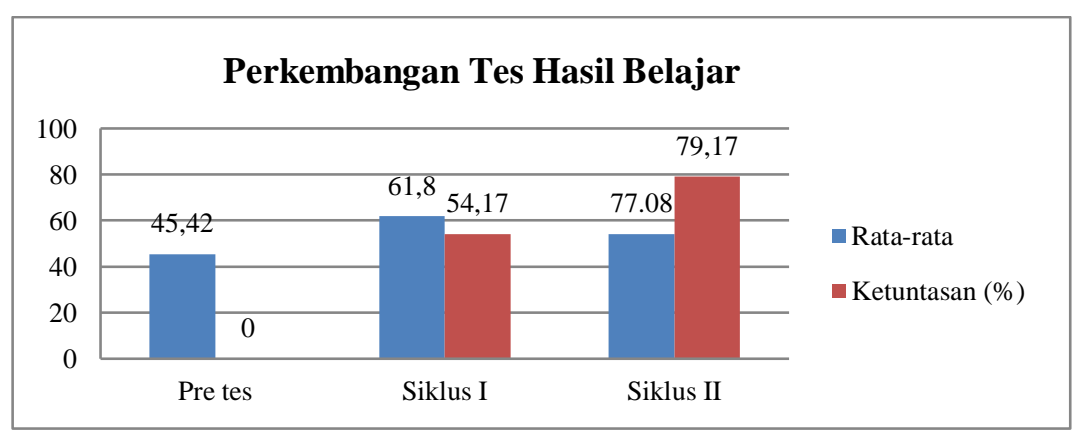

Gambar 3. Tes Hasil Belajar Kemampuan Berpikir Kritis

Pada tes kemampuan berpikir kritis, terdapat peningkatan nilai tes awal dengan tes siklus I, dan semakin meningkat dengan kriteria tinggi pada semua aspek berpikir kritis pada siklus II. Hal ini menunjukkan terdapat pengaruhnya terhadap hasil belajar artinya terdapat perubahan pola berpikir pada siswa setelah siswa mengikuti pembelajaran, hal ini karena karena tujuan utama dalam pembelajaran adalah adanya perubahan pada diri siswa, dari yang sebelumnya tidak tahu menjadi tahu. Seperti yang diungkapkan oleh Sudjana (2017) bahwa belajar adalah proses melihat, megamati dan memahami sesuatu sehingga setelah tahu, maka akan terjadi perubahan pada diri siswa baik secara afektif dan kognitif siswa sehingga akan merubah perilaku siswa.

Senada dengan pengaruh dari pembelajaran Karwono dan Mularsih (2012: 20) menjelaskan bahwa pembelajaran dapat dimaknai dan ditelaah secara mikro dan makro, secara mikro pembelajaran suatu proses yang diupayakan agar peserta didik dapat mengoptimalkan potensi yang dimiliki baik kognitif dan sosioemosional secara efektif dan efisien untuk mencapai perubahan perilaku yang diharapkan. Sedangkan pembelajaran secara makro terkait dengan dua jalur yaitu individu yang belajar dan penataan komponen eksternal agar terjadi proses belajar pada individu yang belajar.

Didukung oleh hasil penelitian yang dilakukan oleh Fakhriyah (2014) yang menyatakan bahwa salah satu keunggulan dari model pembelajaran problem based learning yaitu mampu melatih mahasiswa dalam menggunakan berbagai konsep, prinsip dan keterampilan yang telah mereka pelajari untuk memecahkan permasalahan yang sedang dihadapi. Dengan penerapan problem based learning, kemampuan berpikir kritis dapat berkembang, kemampuan berpikir kritis berupa kemampuan mengidentifikasi, menganalisis, memecahkan masalah, menumbuhkan cara berpikir logis serta membuat keputusan dengan tepat serta dapat menarik kesimpulan.

Penelitian terkait penerapan model problem based learning juga dilaksanakan oleh Hartati dan solihin (2015) meningkatnya kemampuan berpikir kritis siswa melalui implementase model problem based learning pada pembalajaran terpadu.

\section{KESIMPULAN}

Berdasarkan analisis data dan pembahasan yang telah di sajikan, dapat disimpulkan bahwa penerapan model pembelajaran Problem Base Learning mampu meningkatkan kemampuan berpikir kritis siswa. Berdasarkan data observasi pembelajaran Problem Base Learning pada 
siklus I diperoleh rata-rata 57,80\% dengan kategori rendah, sedangkan pada siklus II berhasil mengalami peningkatan mencapai 79,38\% kategori tinggi. Selain itu tes hasil belajar juga mengalami peningkatan ketuntasan KKM, pada siklus I dieroleh rata-rata kelas 61,80 dengan $54,17 \%$ dan pada siklus II rata-rata tes hasil belajar 77,08 dengan ketuntasan KKM 79,17\%. Penerapan model pembelajaran Problem Based Learning sangat cocok digunakan untuk materi pemecahan masalah-masalah yang berkenaan dengan kehidupan sehari-hari.

\section{DAFTAR PUSTAKA}

Budiati, Asih. (2021). Penerapan pembelajaran Berbasis Masalah untuk Meningkatkan Kemampuan Berpikir Kritis dan Hasil Belajar IPA Siswa MTs N I Bantul. Jurnal Inovasi Pendidikan Menengah. Volume I No.1

Fakhriyah. F. (2014). Penerapan Problem Based Learning dalam Upaya Mengembangkan Kemampuan Berpikir Kritis mahasiswa. http://journal.unnes.ac.id/nju/index.php/jpii

Hartati dan solihin. (2015). Meningkatnya kemampuan berpikir kritis siswa melalui implementase model problem based learning pada pembalajaran terpadu.Prosiding symposium Nasional Inovasi dan Pembelajaran sains 2015.

Herzon . Hayuna Hamdalia., Budijanto,. Utomo, Dwiyono Hari (2017). Pengaruh Problem Base Learning terhadap Keterampilan Berpikir Kritis. http://journal.um.ac.id/indeks.php/jptpp/

Karwono dan Mularsih, Heni. (2012). Belajar dan Pembelajaran serta Pemanfaatan Sumber. Raja Grafindo. Jakarta.

Kemendikbud (2013b). Materi Pelatihan Guru Implementasi Kurikulum 2013. Kemendikbud. Jakarta.

Komalasari, Kokom. (2013). Pembelajaran Kontekstual Konsep dan Aplikasi. Refika Aditama. Bandung.

Sani dan Sudiran. (2016). Penelitian Tindakan Kelas Pengembangan Profesi Guru. TSmart. Tangerang.

Sani, Ridwan Abdullah. (2014). Pembelajaran Saintifik untuk Implementasi Kurikulum 2013. Bumi Aksara. Jakarta.

Sudjana, Nana. (2016) Dasar-dasar Proses Belajar Mengajar. Algesindo. Bandung.

Trianto. ( 2011). Mendesain Model Pembelajaran Inovatif dan Progresif. Kencana. Jakarta.

Wisudawati, Asih dan Sulistyowati, Eka. (2014). Metodologi Pembelajaran IPA. Bumi Aksara. Jakarta. 